\title{
Transfection of the Anaerobe Bacteroides thetaiotaomicron with Phage DNA
}

\author{
By SHARON J. BURT AND D. R. WOODS \\ Department of Microbiology, Rhodes University, Grahamstown, 6I 40, South Africa
}

(Received 23 May 1977)

\begin{abstract}
The properties of a Bacteroides thetaiotaomicron phage, $\beta_{1}$, are described. Phenol-extracted phage $\beta_{1}$ DNA transfects $\mathrm{Ca}^{2+}$-treated $B$. thetaiotaomicron cells and transfection is not limited to a particular stage in the growth cycle. An obligatory step in the transfection procedure is a 33 -fold dilution in broth, allowing replication of the infected cells. Prolonged incubation of treated cells with DNA prior to dilution in broth results in a large decrease in phage titre. The application of this system to the investigation of the genetics of obligate anaerobes is discussed.
\end{abstract}

\section{INTRODUCTION}

Studies on obligate anaerobes are at present hampered by the lack of a genetic system (Morris, 1976). As the factors governing competence for transfection and transformation are often very similar (Riva \& Polsinelli, I968), studies on transfection in the obligate anaerobe Bacteroides thetaiotaomicron were undertaken in order to define the conditions required for the uptake of DNA. Mandel \& Higa (I970) described the calcium treatment of Escherichia coli cells which allowed transfection by $\lambda$ DNA. This method has been successfully applied to various nucleic acids of viral (Sjöström, Lindberg \& Philipson, 1972; Taketo, 1974; Bursztyn et al., I975), plasmid (Cohen, Chang \& Hsu, 1972) and bacterial origin (Lindberg, Sjöström \& Johansson, I972; Cosloy \& Oishi, I973).

Strains of $B$. thetaiotaomicron were formerly recognized as subspecies of Bacteroides fragilis but the species rank has recently been restored as a result of DNA homology studies (Cato \& Johnson, I976). As this is also the first report of a $B$. thetaiotaomicron phage, the characteristics of the phage are briefly described.

\section{METHODS}

Bacteria and bacteriophage. The bacteriophage host was $B$. thetaiotaomicron, isolated from a human faecal sample. The bacterium was identified as $B$. thetaiotaomicron and this was confirmed by $D r$ L. V. Holdeman, V.P.I. and S. U. Anaerobic Laboratory, Blacksburg, Virginia, U.S.A. The phage, $\beta_{1}$, was isolated from sewage from an anaerobic digester by conventional methods (Adams, 1959).

Phage techniques. Brain-heart infusion (BHI) broth and agar were used for phage and bacterial propagation (Burt \& Woods, 1976). Exponential phase cultures were infected with phage at a multiplicity of infection of 0.01 and lysis occurred within 2 to $3 \mathrm{~h}$. Concentration and purification of phage lysates was achieved by two cycles of differential centrifugation at $6000 \mathrm{~g}$ for $10 \mathrm{~min}$ and at $57500 \mathrm{~g}$ for $90 \mathrm{~min}$. Single step growth curves, adsorption kinetics and inactivation by antiserum, ultraviolet light (u.v.) and heat were determined by the methods of Adams (1959).

Preparation of DNA. Phage DNA was extracted by a modified procedure of Sjöström et al. (1972). Sodium dodecyl sulphate was added to the concentrated phage suspension to a final concentration of $1 \%(\mathrm{w} / \mathrm{v})$ and the suspension was incubated at room temperature for $30 \mathrm{~min}$. DNA was extracted by the water-saturated phenol technique. The DNA had a u.v. absorption ratio $(260 / 280 \mathrm{~nm}$ ) of $\mathrm{I} \cdot 8$ to $2 \cdot 0$. 
Assay for infectious DNA. Competent bacteria were prepared by the method of Mandel \& Higa (1970). An overnight culture was diluted 200-fold in BHI broth and incubated for $5 \mathrm{~h}$, to an extinction of 0.85 at $600 \mathrm{~nm}$. The cells were cooled quickly, harvested by centrifuging at $4^{\circ} \mathrm{C}$ and resuspended in an equal volume of cold $0.1 \mathrm{M}-\mathrm{MgCl}_{2}$. The cells were then recentrifuged and resuspended in half of the original volume of cold $0.1 \mathrm{M}-\mathrm{CaCl}_{2}$, and kept at $0{ }^{\circ} \mathrm{C}$ for $20 \mathrm{~min}$. The cells were finally centrifuged and resuspended in onetenth of the original volume of $0.1 \mathrm{M}-\mathrm{CaCl}_{2}$. Phage DNA (O.I ml) in standard saline citrate buffer (O.15 M$\mathrm{NaCl} / 0.015 \mathrm{M}$-sodium citrate, $\mathrm{pH} 7.0$ ) was added to $0.2 \mathrm{ml}$ cells and kept at $0^{\circ} \mathrm{C}$ for $15 \mathrm{~min}$. The cell/DNA mixture was given a heat pulse of either $2 \mathrm{~min}$ at $42^{\circ} \mathrm{C}$ or $10 \mathrm{~min}$ at $37^{\circ} \mathrm{C}$, diluted into ro $\mathrm{ml}$ prewarmed broth, and incubated for 2 to $4 \mathrm{~h}$ before plating for plaque-forming units (p.f.u.) by the double agar layer technique (Adams, 1959).

Penicillin sphaeroplasts. Sphaeroplasts were prepared by the methods of Thomson \& Woods (1973). Microscopic examination after incubation with penicillin revealed that 95 to $100 \%$ of the cells had been converted to sphaeroplasts. After the penicillin treatment, $25 \mu \mathrm{g}$ protamine sulphate $\mathrm{ml}^{-1}$ was added, and the sphaeroplasts were stored on ice. Equal volumes of DNA and sphaeroplasts were mixed and incubated for 10 to $60 \mathrm{~min}$ prior to assaying for p.f.u.

\section{RESULTS}

\section{Properties of phage $\beta_{1}$}

Phage $\beta_{1}$ is specific for the anaerobe $B$. thetaiotaomicron and has a hexagonal head, tail (I $44 \mathrm{~nm}$ ) and a base plate but no visible fibres (Fig. I $a$ ). Electron micrographs of concentrated phage lysates indicated the presence of many defective phage particles without tails, which either contained phage DNA or were empty, and appeared to be of two different sizes (Fig. I $a, b$ ). The ratio of defective phage to whole phage, determined by counting I 7 electron micrographs, was $99: 1$. The viable phage particles banded in a single peak with a density of $\mathrm{I} \cdot 44 \mathrm{~g} \mathrm{ml}^{-1}$ and were separated from the defective phage particles by caesium chloride equilibrium centrifugation at $130000 \mathrm{~g}$ for $23 \mathrm{~h}$ (Fig. 2). Electron micrographs from the p.f.u. peak (fractions 13 to 20 ) showed mostly whole phage (Fig. I $c$ ) but electron micrographs from the protein peak (fractions 19 to 22) only showed defective particles (Fig. I $d$ ). Few free phage tails were observed in electron micrographs. Stability studies assessed by p.f.u. assays in different buffers showed no loss in viability at 4,20 or $37^{\circ} \mathrm{C}$. Thermal inactivation studies at 60 and $70^{\circ} \mathrm{C}$ showed no loss in viability after $\mathrm{I} \mathrm{h}$ at $60^{\circ} \mathrm{C}$ but $100 \%$ inactivation after $5 \mathrm{~min}$ at $70^{\circ} \mathrm{C}$. The burst size of the phage was found to vary from 16 to 290 in seven different experiments. The phage had a neutralization constant with antiserum of $123.5 \mathrm{~min}^{-1}$, an adsorption constant at $37{ }^{\circ} \mathrm{C}$ of $4 \times 10^{-10} \mathrm{ml} \mathrm{min}^{-1}$ and a u.v. inactivation constant of $0.0 \mathrm{I} \mathrm{s}^{-1}$ (Adams, 1959). The phage contained doublestranded DNA, which had a $T_{m}$ of $83{ }^{\circ} \mathrm{C}$ and a GC ratio of $33.4 \mathrm{~mol} \%$.

\section{Carrier state}

Turbid plaques were observed occasionally and the resistant colonies were isolated from the centre of a turbid plaque. A phage-resistant clone, which produced phage, was obtained and the stability of this association was investigated by determining the persistence of phage in progeny from six consecutive colonial subcultures. After each of six clonings, 40 colonies were tested for phage production and phage resistance. The number of colonies after each cloning which produced phage spontaneously varied from 25 to $90 \%$ and the number of colonies resistant to phage varied between 49 and $100 \%$. The carrier state was eliminated by a single passage through phage antiserum. This indicates that the carrier state is not true lysogeny as lysogens continue to produce phage after antiserum treatment. The phage was not induced by u.v. irradiation, mitomycin C (Calbiochem, B grade), temperature or ageing. 

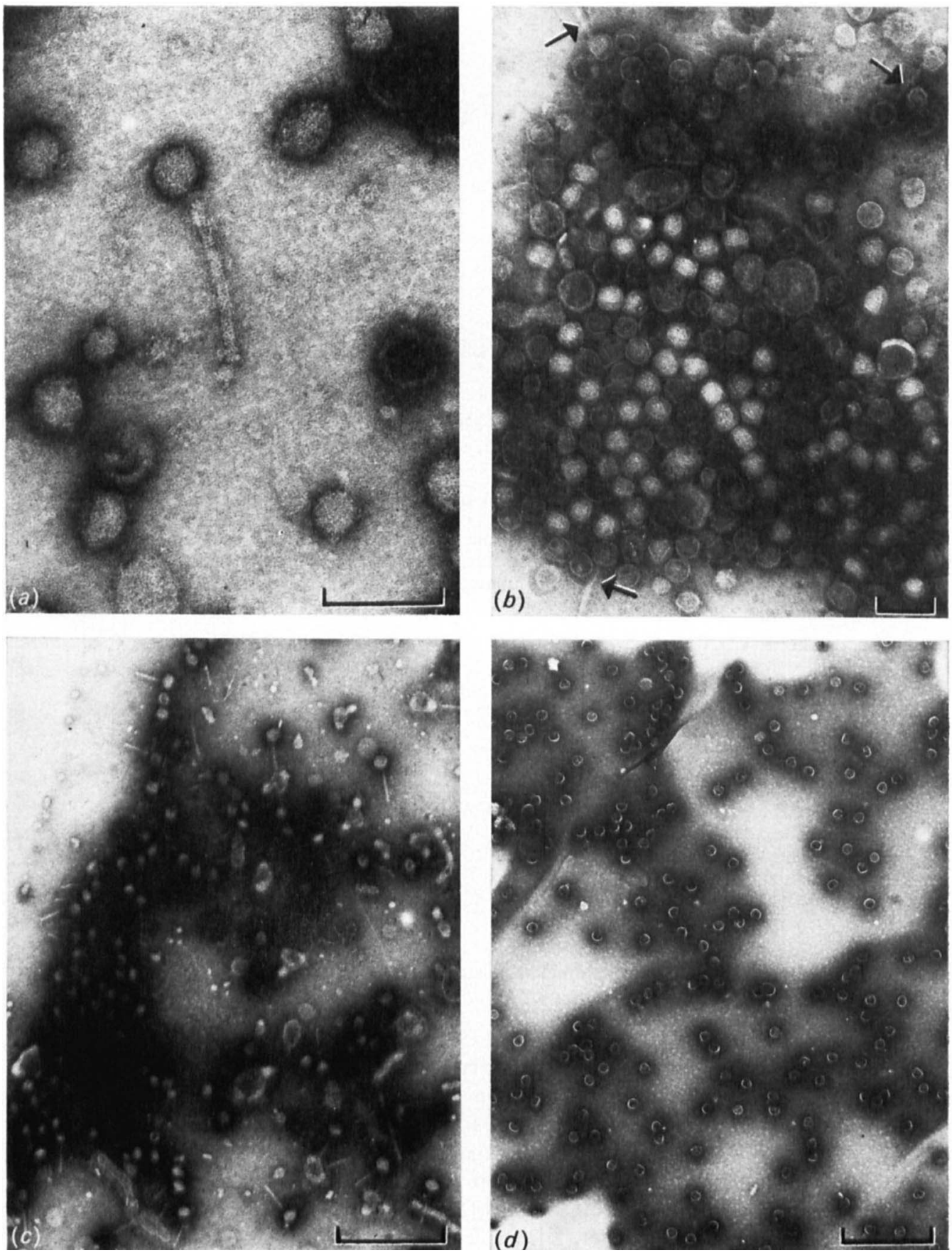

Fig. I. Electron micrographs of $\boldsymbol{B}$. thetaiotaomicron phage. (a) Intact phage and defective phage. Bar marker represents $100 \mathrm{~nm}$. (b) Concentrated phage lysate showing excess of defective phage. Intact phage particles are indicated by arrows. Bar marker represents $100 \mathrm{~nm}$. (c) Intact particles from p.f.u. peak (fractions 13 to 20 ) after density gradient centrifugation (see Fig. 2). Bar marker represents $500 \mathrm{~nm}$. (d) Defective particles from protein peak (fractions I9 to 22, see Fig. 2). Bar marker represents $500 \mathrm{~nm}$. 


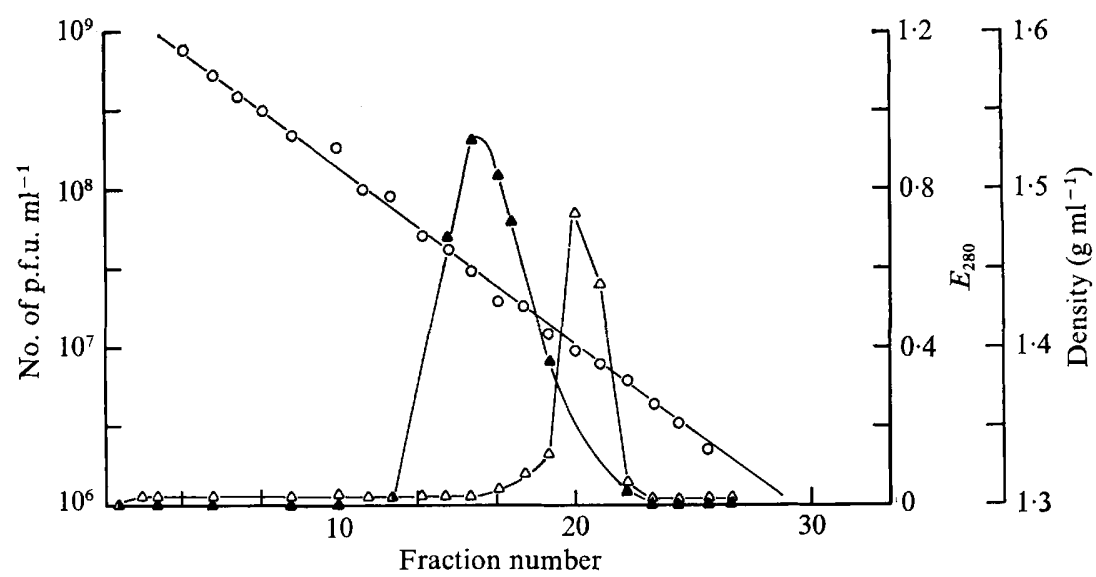

Fig. 2. Fractionation of intact and defective phage particles by $\mathrm{CsCl}$ density gradient centrifugation. $\triangle$, Infectivity (p.f.u. $\left.\mathrm{ml}^{-1}\right) ; \Delta$, extinction at $280 \mathrm{~nm}$; $\mathrm{O}$, density $\left(\mathrm{g} \mathrm{ml}^{-1}\right)$.

\section{Table I. Identification of the infective principle}

Phage $\beta_{1}$ DNA was treated as described in the Table; $0.1 \mathrm{ml}$ was then added to $0.2 \mathrm{ml} \mathrm{Ca}^{2+}$ treated cells at $0^{\circ} \mathrm{C}$ and the mixture was incubated at $42{ }^{\circ} \mathrm{C}$ for $2 \mathrm{~min}$. The cell/DNA mixture was diluted into ro $\mathrm{ml} \mathrm{BHI}$ broth and incubated for $4 \mathrm{~h}$ prior to plating by the soft agar layer technique. Final DNA concentration $6.5 \mu \mathrm{g} \mathrm{ml}^{-1}$.

Treatment

\section{Control}

No DNA

No cells

Cells untreated with $\mathrm{Ca}^{2+}$

Sphaeroplasts

DNA preincubated with $2 \mu \mathrm{g}$ DNAase $\mathrm{ml}^{-1}$ for $5 \mathrm{~min}$ at $37^{\circ} \mathrm{C}$

DNA + cells incubated with $2 \mu \mathrm{g}$ DNAase $\mathrm{ml}^{-1}$ after

2 min heat pulse

DNA preincubated with $20 \mu \mathrm{g}$ RNAase $\mathrm{ml}^{-1}$

for $30 \mathrm{~min}$ at $37^{\circ} \mathrm{C}$

DNA preincubated with $20 \mu \mathrm{g}$ pronase $\mathrm{ml}^{-1}$

for $30 \mathrm{~min}$ at $37^{\circ} \mathrm{C}$

Control (no protamine sulphate)

$\mathrm{Ca}^{2+}$-treated cells with $25 \mu \mathrm{g}$ protamine sulphate $\mathrm{ml}^{-1}$

$\begin{array}{cc}\text { No. of p.f.u. } \mathrm{ml}^{-1} & \% \text { of control } \\ \mathrm{I} \cdot 5 \times 10^{4} & 100 \\ 0 & 0 \\ 0 & 0 \\ 0 & 0 \\ 0 & 0 \\ 0 & 0\end{array}$

$1 \cdot 3 \times 10^{4} \quad 87$

$1 \cdot 2 \times 10^{4}$

$1 \cdot 0 \times 10^{4}$

$5.6 \times 10^{4}$

$8.6 \times 10^{4}$

\section{Transfection}

Phage $\beta_{1}$ DNA was shown to be the infective agent in the $B$. thetaiotaomicron transfection system (Table I). Infectivity was lost when the DNA was preincubated with DNAase, but RNAase and pronase had little effect. However there was $13 \%$ reduction in transfection when the cell/DNA mixture was treated with DNAase after the 2 min heat pulse treatment. Transfection only occurred when cells were treated with $0 . \mathrm{I} \mathrm{M}-\mathrm{CaCl}_{2}$ and did not occur with penicillin sphaeroplasts. Protamine sulphate, which enhances transfection of $E$. coli sphaeroplasts (Benzinger, Kleber \& Huskey, I97I), did not affect transfection in $B$. thetaiotaomicron.

The number of p.f.u. increased with phage DNA concentrations between $\mathrm{I} \cdot 6$ and $6.5 \mu \mathrm{g}$ $\mathrm{ml}^{-1}$ (Table 2). Further increases in DNA concentration did not markedly increase the number of p.f.u.

Competence for transfection throughout the growth cycle of $B$. thetaiotaomicron was determined. No relationship was found as cells at various growth stages were equally competent. However, the degree of competence varied greatly between different cultures of the $B$. thetaiotaomicron strain. 
Table 2. Effect of DNA concentration on the number of p.f.u.

Various amounts of DNA were distributed into tubes containing $0.2 \mathrm{ml} \mathrm{Ca}^{2+}$-treated cells at $0{ }^{\circ} \mathrm{C}$. Mixtures were heated for $2 \mathrm{~min}$ at $42{ }^{\circ} \mathrm{C}$, diluted into $10 \mathrm{ml} \mathrm{BHI}$ broth and incubated for $4 \mathrm{~h}$ prior to plating by the soft agar layer technique.

$\begin{array}{cc}\text { DNA concn }\left(\mu \mathrm{g} \mathrm{ml}^{-1}\right) & \left.\text { Titre (p.f.u. } \mathrm{ml}^{-1}\right) \\ \mathrm{I} \cdot 6 & 8.9 \times 10^{8} \\ 3 \cdot 25 & \mathrm{I} \cdot 5 \times 10^{9} \\ 6.5 & 9 \cdot 4 \times 10^{9} \\ \mathrm{I} 3 & 9.3 \times 10^{9}\end{array}$

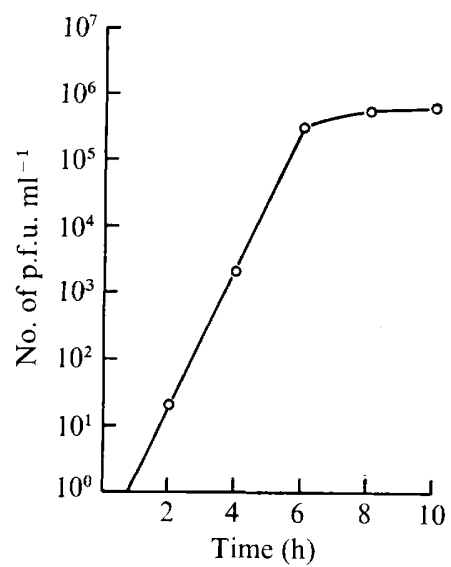

Fig. 3

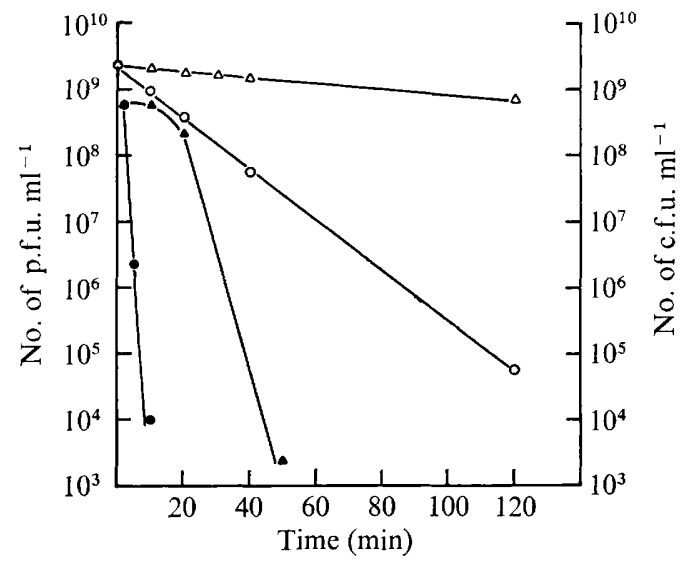

Fig. 4

Fig. 3. Kinetics of appearance of p.f.u. after dilution of the cell/DNA mixture. A cell/DNA mixture was heated at $42^{\circ} \mathrm{C}$ for $2 \mathrm{~min}$, diluted in $10 \mathrm{ml} \mathrm{BHI}$ broth and incubated at $37^{\circ} \mathrm{C}$. Samples were removed at intervals and assayed for p.f.u. Final DNA concentration $10 \mu \mathrm{g} \mathrm{ml}^{-1}$.

Fig. 4. Kinetics of transfection and viability of $\mathrm{Ca}^{2+-t r e a t e d ~ c e l l s ~ a t ~} 37$ and $42^{\circ} \mathrm{C}$. Cell/DNA mixtures were incubated at $37^{\circ} \mathrm{C}(\Delta)$ or $42^{\circ} \mathrm{C}(\odot)$, sampled at intervals, diluted into Io $\mathrm{ml}$ BHI broth, incubated at $37^{\circ} \mathrm{C}$ for $4 \mathrm{~h}$ and assayed for p.f.u. Cells treated with $\mathrm{Ca}^{2+}$ at $0{ }^{\circ} \mathrm{C}$ were incubated at $37^{\circ} \mathrm{C}(\triangle)$ or $42^{\circ} \mathrm{C}(O)$ and samples were removed at intervals, diluted and plated to determine cell viability. Final DNA concentration $13 \mu \mathrm{g} \mathrm{ml}^{-1}$.

No transfection was observed when the cell/DNA mixture was plated immediately after the heat pulse treatment. Transfection was only detected after the cell/DNA mixture was diluted 33-fold into BHI broth and incubated for 2 to $4 \mathrm{~h}$ before plating (Fig. 3). No p.f.u. (detectable at a level of 5 p.f.u. $\mathrm{ml}^{-1}$ ) were produced when the cell/DNA mixture was diluted 0 - to I2-fold. Because the conditions now favour continued cycles of phage replication, it must be emphasized that the p.f.u. do not represent primary infections as the time interval of incubation is greater than the minimum latent period of intact phage adsorbed to these bacteria.

As the transfection procedure usually involves chilling at $0{ }^{\circ} \mathrm{C}$ and a heat pulse of either Io min at $37^{\circ} \mathrm{C}$ or $2 \mathrm{~min}$ at $42^{\circ} \mathrm{C}$, the effect of temperature on transfection was investigated. Transfection occurred at $0{ }^{\circ} \mathrm{C}$ without a heat pulse, and heating the cells for 2 min at $42{ }^{\circ} \mathrm{C}$ did not affect the number of p.f.u. However, further incubation of the $\mathrm{Ca}^{2+}$-treated cell/ DNA mixture at $42{ }^{\circ} \mathrm{C}$ for Io min or $37^{\circ} \mathrm{C}$ for $50 \mathrm{~min}$ resulted in a marked decrease in the number of p.f.u. (Fig. 4). This is probably due to the lethal effects of $\mathrm{Ca}^{2+}$ at high concentrations, as the viable cell count decreased simultaneously with the decrease in p.f.u. No loss in the viability of the cells was observed when cells and DNA were mixed in the absence of $\mathrm{Ca}^{2+}$. 


\section{DISCUSSION}

Phage $\beta_{1}$, used in the transfection studies, is interesting as an excess of defective particles of two different sizes were observed in phage lysates, even after repeated cloning. The reason for the production of defective particles at a high frequency is not known and is part of a further study being undertaken to elucidate the $\beta_{1}$ phage-host relationship. However, the defective particles are unlikely to be due to instability of the whole phage, as the phage, assessed by p.f.u., was very stable and few free phage tails were observed in electron micrographs. The defective particles are not likely to be another spontaneously produced phage without a tail as concentrated filtrates of uninfected or u.v.-induced bacterial cultures had no observable phage particles. Phage were only obtained when sensitive bacteria were infected with the $\beta_{1}$ phage.

Mosig (1963) reported the production of small $\mathrm{T}_{4}$ particles, which had a lower buoyant density in $\mathrm{CsCl}$ than the average particles and were not viable. These particles contained short DNA molecules which prevented normal assembly (Chao, Chao \& Speyer, 1974). The smaller 'heads' of phage $\beta_{1}$ may arise in a similar manner. Serological and other studies are in progress to determine whether the different structures visible in electron micrographs have the same origin.

The pseudolysogeny we have observed with phage $\beta_{1}$ is similar to that reported by Keller \& Traub (1974) for a Bacteroides fragilis phage. Since there is an alteration between phageresistant and phage-sensitive phenotypes, the phage carrier state may be due to the continuous development of phage-sensitive bacteria from a phage-resistant population.

Competence for transfection in $B$. thetaiotaomicron required that the cells were suspended in a reaction medium containing high concentrations of $\mathrm{Ca}^{2+}$ but was not limited to a particular stage in the growth cycle. Taketo (1974) found a similar effect with $E$. coli cells, but Sjöström et al. (1972) found that competence in Staphylococcus aureus was limited to a short period in early exponential phase. Although the competent cells were prepared by a standard growth method, the number of transfectants varied greatly when the same DNA was used in different experiments. This appears to be a common feature of some transfection systems as Földes \& Trautner (1964) observed large variations in p.f.u. with Bacillus subtilis between experiments using the same DNA concentrations. Benzinger \& Kleber (I97I) found that only I out of I5 penicillin sphaeroplast preparations of $E$. coli was optimally competent. A further example of the sensitivity of the cell/DNA mixtures in transfection was reported by Földes \& Trautner (1964) who showed that in the transfection of Bacillus subtilis extreme care had to be taken in the handling of cell/DNA mixtures.

Transfection occurred at $0^{\circ} \mathrm{C}$ and the heat pulse, although effective, was not essential for DNA uptake. Cohen et al. (1972) found that no uptake of R plasmid DNA by E. coli occurred unless the cells were given a heat pulse. Burt \& Woods (1976) reported that $R$ plasmid transfer from $E$. coli to Bacteroides spp. was possible after heat treatment of the recipients for $20 \mathrm{~min}$ at $50^{\circ} \mathrm{C}$.

A feature of the transfection system was the necessity for both the 33 -fold dilution of the cell/DNA mixture and the subsequent 2 to $4 \mathrm{~h}$ growth period. The reasons for these requirements are not known but Romig (1962) found a similar requirement for replication of infected Bacillus subtilis cells before plaques were detected. The 20-fold dilution step may be necessary to reduce the concentration of $\mathrm{Ca}^{2+}$ below a certain level for transfection.

The thermosensitivity of the transfection system can be partly explained by a loss of viability of the $\mathrm{Ca}^{2+}$-treated cells, although the number of transfectants decreased more rapidly than the number of viable cells. It is unlikely that nuclease activity contributes to this thermosensitivity as treatment of the cell/DNA mixture with DNAase after the 2 min heat pulse only resulted in a $13 \%$ decrease in the number of p.f.u.

This is the first report of phage DNA uptake in a Bacteroides species. In other bacterial species, $\mathrm{Ca}^{2+}$ is necessary for the uptake of bacterial DNA resulting in the transformation 
of antibiotic resistance and auxotrophic markers (Lindberg et al., 1972; Cosloy \& Oishi, 1973). Since spontaneous genetic transfer has not been described in Bacteroides species (Burt \& Woods, 1976), the transfection procedure described may be utilized to develop a transformation system.

We thank Mr R. Cross for the electron micrographs and D.R.W. acknowledges a research grant from the South African Medical Research Council.

\section{REFERENCES}

ADAMS, M. H. (1959). Bacteriophages. New York: Interscience Publishers.

Benzinger, R. \& KLEBER, I. (1971). Transfection of $E$. coli and $S$. typhimurium spheroplasts: hostcontrolled restriction of infective bacteriophage P22 DNA. Journal of Virology 8, 197-202.

BENZINGER, R., KIEBER, I. \& HuSKEY, R. (197I). Transfection of $E$. coli spheroplasts. General facilitation of double-stranded DNA infectivity by protamine sulphate. Journal of Virology 7, 646-650.

Bursztyn, H., Sgaramella, V., Ciferri, O. \& LEDERBERG, J. (1975). Transfectability of rough strains of $S$. typhimurium. Journal of Bacteriology I24, I630-I634.

BurT, S. J. \& Woods, D. R. (I976). R factor transfer to obligate anaerobes from Escherichia coli. Journal of General Microbiology 93, 405-409.

CAto, E. P. \& Johnson, J. L. (I976). Reinstatement of species rank for $B$. fragilis, B. ovatus, B. distasonis, $B$. thetaiotaomicron, and $B$. vulgatus: designation of neotype strains for $\boldsymbol{B}$. fragilis (Veillon \& Zuber) Castellani and Chalmers and $B$. thetaiotaomicron (Distaso) Castellani and Chalmers. International Journal of Systematic Bacteriology 26, 230-237.

Chao, J., Chao, L. \& Speyer, J. F. (I974). Bacteriophage $T_{4}$ head morphogenesis: host DNA enzymes affect frequency of petite forms. Journal of Molecular Biology 85, 4I-50.

Cohen, S. N., Chang, A. C. Y. \& Hsu, L. (1972). Non-chromosomal antibiotic resistance in bacteria: genetic transformation of $E$. coli by Rfactor DNA. Proceedings of the National Academy of Sciences of the United States of America 69, $2110-2114$.

CosLoY, S. D. \& OISHI, M. (1973). Genetic transformation in E. coli KI2. Proceedings of the National Academy of Sciences of the United States of America 70, 84-87.
Földes, J. \& TrautNer, T. A. (1964). Infectious DNA from a newly isolated $B$. subtilis phage. Zeitschrift für Vererbungslehre 95, 57-65.

KelleR, R. \& TraUB, N. (I974). The characterization of Bacteroides fragilis bacteriophage recovered from animal sera: observations on the nature of Bacteroides phage carrier cultures. Journal of General Virology 24, 179-189.

LINDBERG, M., SJöSTRÖM, J. \& JoHANSSON, T. (I972). Transformation of chromosomal and plasmid characters in S. aureus. Journal of Bacteriology I09, 844-847.

Mandel, M. \& Higa, A. (1970). Calcium-dependent bacteriophage DNA infection. Journal of Molecular Biology 53, I 59-162.

MorRIS, J. G. (I976). Oxygen and the obligate anaerobe. Journal of Applied Bacteriology 40, 229-244.

Mosig, G. (I963). Coordinate variation in density and recombination potential in $T_{4}$ phage particles produced at different times after infection. Genetics 48, I 195-I 200.

Riva, S. \& Polsinelli, M. (1968). Relationship between competence for transfection and for transformation. Journal of Virology 2, 587-593.

Romig, W. R. (1962). Infection of $B$. subtilis with phenol-extracted bacteriophages. Virology I6, $452-459$.

Sjöström, J., Lindberg, M. \& Philipson, L. (1972). Transfection of S. aureus with bacteriophage DNA. Journal of Bacteriology 109, 285-29r.

TAKeTo, A. (I974). Sensitivity of $E$. coli to viral nucleic acid. VIII. Idiosyncrasy of $\mathrm{Ca}^{2+}$-dependent competence for DNA. Journal of Biochemistry $\mathbf{7 5}$, 895-904.

Thomson, J. A. \& Woods, D. R. (1973). Properties of sphaeroplasts of a halotolerant Achromobacter strain and their infection with bacteriophage deoxyribonucleic acid. Journal of General Microbiology 74, $7 \mathrm{I}-76$. 